\title{
Do accrual minimise (maximise) stock risk (return)?: evidence from Indonesia
}

\section{Dedhy Sulistiawan and Felizia Arni Rudiawarni ${ }^{\star}$}

\author{
Accounting Department, \\ University of Surabaya, \\ Jl. Raya Kalirungkut, \\ 60293 Surabaya, \\ East Java, Indonesia \\ Email: dedhy@ubaya.ac.id \\ Email: felizia@staff.ubaya.ac.id \\ *Corresponding author
}

\begin{abstract}
This study investigates the ability of accruals as earnings component to explain stock risk and its return. We believe managers use accruals to maximise firms' value through minimising stock risk and maximising stock return. Using Indonesian data, we find a negative relation between total accruals to stock risk, especially for loss and small firms. We also present a positive relation between total accruals to abnormal return, particularly in profit and large firms. Those phenomena indicate that investors use higher accruals to produce lower stock risk and higher abnormal return. This study contributes to market-based accounting research.
\end{abstract}

Keywords: abnormal return; accruals; stock risk.

Reference to this paper should be made as follows: Sulistiawan, D. and Rudiawarni, F.A. (2017) 'Do accrual minimise (maximise) stock risk (return)?: evidence from Indonesian', Int. J. Globalisation and Small Business, Vol. 9, No. 1, pp.20-28.

Biographical notes: Dedhy Sulistiawan is a Lecturer at Accounting Department University of Surabaya. He received Doctoral degree in Accounting from Gajah Mada University. His research interest is market-based accounting research and behavioural accounting. Now, he is the Head of Accounting Department in University of Surabaya. He has published books and articles in international journals. He also presented his research at several symposiums, including The 13th Conference of Asian Academic Accounting Association (AAAA) 2012 in Kyoto (Japan), and The 14th conference of AAAA 2013 in Penang (Malaysia).

Felizia Arni Rudiawarni is a Lecturer at Accounting Department University of Surabaya. She received master's degree in Accounting from University of Surabaya. She is interested in financial accounting, especially in earnings management. She also published articles in several international journals.

This paper is a revised and expanded version of a paper entitled 'Can We Use Accruals to Minimize Stock Risk and Maximize Return?: Indonesian Evidence', presented at SIBR Kuala Lumpur, February 12-13, 2016, Malaysia. 


\section{Introduction}

The purpose of this study is to examine the ability of accruals information as earnings component to explain stock risk and return. This study substantially develops the idea of Michelson, Wagner and Wootton (1995) and Dechow (1994). Michelson, Wagner, and Wootton (1995) discuss about the impact of income smoothing to market performance and Dechow (1994) examines the ability of accruals to predict stock return. We focus on the relation between accruals information to stock risk and return.

Earnings consist of two components that are: accruals and operating cash flow. This study focusses more on accruals information than operating cash flow, because of several reasons. First, accruals problem is more dominant topic in accounting treatment. Basically, the accurate measurement of earnings depends on the correct matching of revenue (services or goods provided) and expenses (costs of providing services or good; Ambarriani, 2014). In practice, accruals are used to change the timing of cash flow recognition in accounting (Dechow, 1994). Second, we assume that managing accruals transactions are easier than managing real cash transaction, which in turn stimulates other problem, called earnings management. Previous studies show that managers are motivated to manage earnings (Jones, 1991; Liberty and Zimmerman, 1986), especially in countries with weak investor's protection (Leuz, Nanda and Wysocki, 2003). Based on Sloan (1996), investors who use earnings with higher accruals tend to be fixated on earnings information. As financial reporting preparers, managers have an opportunity to set reported earnings in order to meet their specific objectives. Managers have very strong incentive to assure that reported earnings can fulfil the expectation of investment communities, so market will respond positively. This study focusses on managers' goal to minimise stock risk and maximise stock return. This study shows that accruals information negatively affects stock risk and positively affects abnormal return. Our findings are expected to contribute to market-based accounting research, especially the use of accruals information as the centre of attention in accounting practice.

This article is divided by several sections. The second part discusses literature review. The third section describes data and methodology. The fourth provides evidence and analysis. The last concludes.

\section{Hypothesis development}

\subsection{Accruals and risk}

Earnings information is one of the most valuable information for investors. Variability of income is highly correlated with overall and systematic risk measures (Lev and Kunitzky, 1974). Therefore, by managing accruals, managers have the ability to control reported earnings stream. Stable earnings give owners and creditors more confident feelings about managers' performance (Gordon, 1964; Michelson, Wagner and Wootton, 1995 and Hepworth, 1953).

Bartov, Givoly and Hayn (2002) found that market tends to react negatively to firms that experience negative earnings surprise. Stock prices fall significantly (i.e., negative abnormal return), and even, they suffer greater decline in their stock prices rather than reward that they deserve if they can meet or beat investors' expectation. As a 
consequence, manager has very strong incentive to ensure reported earnings so that it can meet or beat the expectation of investment community. Based on that phenomenon, higher accruals mean lower risk and higher returns. Our hypothesis is stated as follows.

\section{H1: Total accruals negatively affect stock risk.}

\subsection{Accruals and return}

Market participants react to the events or announcement that reflected in abnormal return (Gunaasih and Nursasmito, 2015). We also believe that earnings information is the trigger of that reaction. Earnings consist of two components, which are accruals and operating cash flow. But investors cannot differentiate the ability of those components to predict future profit (Sloan, 1996). Earnings increases caused by higher accruals show lower earnings persistence, which leads to low earnings quality. Higher accruals relative to cash flow is as a signal for earnings management. In this case, operating cash flow has better capability rather than accruals to predict future profitability. But since investors fail to value operating cash flow information in earnings, they tend to be more optimistic about the prospect of firms with higher accruals and too pessimistic about the prospect of firms with lower accruals (Hirshleifer, Hou and Teoh, 2012). Collins and Hribar (2000) also find that market tends to overestimate the persistence of accruals component, so they tend to overprice accruals in the current year.

As a provider of financial information, managers have certain level of discretion to present earnings figure, including accruals as a part of earnings component. According to Healy (1985), managers manage earnings through accruals. Based on those arguments, our hypothesis is stated as below.

\section{$\mathrm{H}_{2}$ : Higher accruals lead to higher abnormal return}

\section{Data and methodology}

This study examines all firms listed in Indonesia Stock Exchange, except for banking and financial institution industry for the period of 2010-2013. The data for computing total accruals, operating cash flow and size are collected from Indonesian Stock Exchange website, while the data for computing return and risk are gathered from Yahoo Finance. We use Indonesian data because of two reasons. First, the results of Leuz, Nanda and Wysocki (2003) and Defond, Hung and Trezevant (2007) show that countries with low protection for investors produce higher tendency to lower accounting quality. Indonesia is one of those countries (Fan and Wong, 2002). Second, developing markets tend to produce higher volatility. It means that Indonesian market also produce higher risk compare to other countries. We combine both of those ideas to conduct research in Indonesia. Those reasons make this research becomes contextual.

Total accruals (TACC) are computed as net income (NI) minus operating cash flow $(\mathrm{OCF})$. For stock risks, we use standard deviation of daily return in year $t$. Abnormal return $t$ is calculated based on the difference between actual return and expected return based on the market model. The models are presented below:

$$
S T D E V_{i, t}=b_{0}+b_{1} T A C C_{i, t}+b_{2} O C F_{i, t}+b_{3} L N_{-} T A_{i, t-1}+b_{4} D U M_{-} Y E A R_{i, t}+e_{i, t}
$$




$$
A B R E T_{i, t}=a_{0}+a_{1} T A C C_{i, t}+a_{2} O C F_{i, t}+a_{3} L N_{-} T A_{i, t-1}+a_{4} D U M_{-} Y E A R_{i, t}+e_{, t}
$$

where

STDEV $=$ standard deviation of return of firm in year $_{t}$.

ABRET $=$ abnormal return of firm $_{i}$ in year ${ }_{t}$.

TACC $=$ net income minus operating cash flow of firm $i$ in the period ${ }_{t}$.

$\mathrm{OCF}=$ operating cash flow of firm $i$ in the period $_{t}$.

LN_TA $=$ natural logarithm of total asset of firm $i$ in the beginning of period ${ }_{t}$.

DUM_YEAR $=$ dummy years.

\section{Results and discussion}

\subsection{Descriptive statistics}

Table 1 presents descriptive statistics of our sample. In average, $\mathrm{TACC}_{\mathrm{t}}$ is not different from zero. In our study, the mean of $\mathrm{TACC}_{\mathrm{t}}$ indicates that our sample provide non-bias sample because of overstatement or understatement of accrual information. $\mathrm{CFO}_{t}$, $\mathrm{LN}_{-} \mathrm{TA}_{\mathrm{t}-1}, \mathrm{STDEV}_{\mathrm{t}}$ and $\mathrm{ABRET}_{\mathrm{t}}$, in average, are positive and significant at $1 \%$. We use Pearson and Spearman univariate correlation coefficients for the several variables. The result shows that Pearson's correlation between TACC $_{t}$ and $\mathrm{STDEV}_{\mathrm{t}}$ indicates a strong relation. Using Spearman's rho test, $\mathrm{TACC}_{\mathrm{t}}$ more relates to $\mathrm{ABRET}_{\mathrm{t}}$ than $\mathrm{STDEV}_{\mathrm{t}}$.

Table 1 Descriptive statistics

\begin{tabular}{lccccc}
\hline & $N$ & Minimum & Maximum & Mean & Std. Deviation \\
\hline TACC $_{\mathrm{t}}$ & 705 & -1.33 & 0.99 & -0.0089 & 0.16030 \\
CFO $_{\mathrm{t}}$ & 703 & -0.63 & 1.45 & $0.0845^{* * *}$ & 0.16589 \\
LN_TA $_{\mathrm{t}-1}$ & 704 & 21.93 & 32.84 & $27.8884 * * *$ & 1.68465 \\
STDEV $_{\mathrm{t}}$ & 703 & 0.00 & 0.60 & $0.0230 * * *$ & 0.02875 \\
ABRET $_{\mathrm{t}}$ & 705 & -0.95 & 10.20 & $0.2313 * * *$ & 0.86467 \\
\hline
\end{tabular}

$* * *, * *$ and $*$ denote significance at the 1,5 and $10 \%$ levels, respectively (two-tailed test).

\subsection{Results}

Table 2 presents estimates of total accruals to stock risk. Table 2 Panel A for all sample, reports that accruals $\left(\mathrm{TACC}_{\mathrm{t}}\right)$ negatively affects stock risk $\left(\mathrm{STDEV}_{\mathrm{t}}\right)$ at $10 \%$ level. It means that higher (lower) accruals produce lower (higher) risk. Using this sample, $\mathrm{H}_{1}$ is supported although it only produces moderately significant result. Operating cash flow $\left(\mathrm{CFO}_{\mathrm{t}}\right)$ produces negative coefficient. Higher (lower) operating cash flow generates lower (higher) risk. Companies' size is statistically insignificant. 
Table 2 The impact of total accruals to stock risk

\begin{tabular}{|c|c|c|c|c|c|c|}
\hline \multicolumn{7}{|c|}{ Panel A: The impact of total accrual to stock risk based on the firms' earnings } \\
\hline & \multicolumn{2}{|c|}{$\operatorname{All}(n=705)$} & \multicolumn{2}{|c|}{ Positive NI $(n=607)$} & \multicolumn{2}{|c|}{ Negative NI $(n=98)$} \\
\hline Variable & Coeff. & t-stat. & Coeff. & t-stat. & Coeff. & t-stat. \\
\hline$C$ & 0.0539 & $2.0270 * *$ & 0.0848 & $9.5737 * * *$ & -0.3483 & -1.1173 \\
\hline $\mathrm{CFO}_{\mathrm{t}}$ & -0.0377 & $-1.3739^{*}$ & -0.0061 & -1.2316 & -0.1960 & -1.2886 \\
\hline $\mathrm{TACC}_{\mathrm{t}}$ & -0.0382 & $-1.3312 *$ & -0.0022 & -0.4404 & -0.1511 & $-1.3465^{*}$ \\
\hline $\mathrm{LN}_{-} \mathrm{TA}_{\mathrm{t}-1}$ & -0.0006 & -0.6362 & -0.0018 & $-6.0378^{* * *}$ & 0.0136 & 1.2176 \\
\hline Dyear11 & -0.0269 & $-8.6263 * * *$ & -0.0306 & $-25.607 * * *$ & -0.0066 & -0.3854 \\
\hline Dyear12 & -0.0023 & $-1.6656^{*}$ & -0.0040 & $-3.1485^{* * *}$ & 0.0010 & 0.1115 \\
\hline$R^{2}$ & 0.2231 & & 0.6067 & & 0.1930 & \\
\hline $\operatorname{Adj} . R^{2}$ & 0.2175 & & 0.6034 & & 0.1491 & \\
\hline S.E. of Regression & 0.0255 & & 0.0112 & & 0.0577 & \\
\hline F-statistic & & 39.8603 & & 183.8398 & & 4.3996 \\
\hline Prob (F-statistic) & & $<0.01$ & & $<0.01$ & & $<0.01$ \\
\hline DW-Statistic & & 2.0818 & & 2.1293 & & 2.0574 \\
\hline \multicolumn{7}{|c|}{ Panel B: The impact of total accrual to stock risk based on the firms' size } \\
\hline & \multicolumn{3}{|c|}{ Smaller $(n=352)$} & \multicolumn{3}{|c|}{ Larger $(n=353)$} \\
\hline Variable & Coeff. & & $t$-stat. & Coeff. & & t-stat. \\
\hline$C$ & 0.0373 & & $9842 * * *$ & 0.0375 & & $6.1280 * * *$ \\
\hline CFOt & -0.0187 & & $.3538 * * *$ & -0.0772 & & -1.1707 \\
\hline TACCt & -0.0094 & & $1.6843 * *$ & -0.0875 & & -1.2207 \\
\hline DYear11 & -0.0327 & -17 & $7.2753^{* * *}$ & -0.0212 & & $-4.1320 * * *$ \\
\hline DYear12 & -0.0016 & & -0.7357 & -0.0027 & & -1.3502 \\
\hline$R^{2}$ & 0.5748 & & & 0.1477 & & \\
\hline Adj. $R^{2}$ & 0.5699 & & & 0.1378 & & \\
\hline S.E. of regression & 0.0137 & & & 0.0324 & & \\
\hline F-statistic & & & 16.5986 & & & 14.9857 \\
\hline Prob(F-statistic) & & & $<0.01$ & & & $<0.01$ \\
\hline DW-Statistic & & & 2.0646 & & & 1.9653 \\
\hline
\end{tabular}

***, ** and $*$ indicate significance at the 1,5 and $10 \%$ levels, respectively. Constanta (C), DYear11 and Dyear12 are two tailed. $\mathrm{CFO}_{\mathrm{t}}, \mathrm{TACC}_{\mathrm{t}}$ and $\mathrm{Ln} \mathrm{TA}_{\mathrm{t}-1}$ are one tailed. $\mathrm{CFO}_{\mathrm{t}}$ is operating cash flow in year t. TACC $\mathrm{t}_{\mathrm{t}}$ is total accruals in year $t . \mathrm{LN}_{-} \mathrm{TA} \mathrm{t}_{\mathrm{t}-1}$ is natural logarithm of total assets at the beginning of year $\mathrm{t}$. $\mathrm{CFO}_{\mathrm{t}}, \mathrm{TACC}_{\mathrm{t}}$ are scaled by total assets at the beginning of year t. DYear11 (DYear12) is 1 when $t=2011(t=2012)$, and 0 otherwise.

We also perform a deeper analysis by splitting sample based on the company that present negative and positive net income. We believe that profit or loss condition affects the relation between earnings component and stock risk. Bernard and Stober (1989) support this argument. The results are presented in Table 2 Panel A for positive and negative net income. Table 2 Panel A for sample with positive net income reports that total accruals $\left(\mathrm{TACC}_{\mathrm{t}}\right)$ are statistically insignificant, it means that $\mathrm{TACC}_{\mathrm{t}}$ are not able to affect stock 
risk. Size that is represented by asset negatively affects total risk. Larger (smaller) companies produce lower (higher) stock risk. Finding in Table 2 Panel A for sample with negative net income supports our first hypothesis. In loss firms, higher (lower) accruals generate lower (higher) stock risk. This result gives evidence about shifting attention phenomena because of firms' condition. Table 2 Panel B gives evidence about the impact of total accruals as earnings component to stock risk based on the firms' size. In Panel B, total accruals negatively affect stock risk for smaller firms, but total accruals are not able to explain stock risk for larger firms. Investors also use operating cash flow to value stock risk for smaller firms but not for larger firms.

The results of our hypothesis testing about abnormal return are reported in Table 3 . Table 3 Panel A for all samples presents that accounting accruals positively affect abnormal return, so $\mathrm{H}_{2}$ is supported. It means that investors use total accruals as their information that in turn will affect abnormal return. This table also informs that operating cash flow positively affects abnormal return. Firms' size negatively affects abnormal return.

Table 3 The impact of total accruals to abnormal return

\begin{tabular}{|c|c|c|c|c|c|c|}
\hline \multicolumn{7}{|c|}{ Panel A: The impact of total accruals to abnormal return based on the firms' earnings } \\
\hline & \multicolumn{2}{|c|}{$\operatorname{All}(n=705)$} & \multicolumn{2}{|c|}{ Positive NI $(n=607)$} & \multicolumn{2}{|c|}{ Negative NI $(n=98)$} \\
\hline Variable & Coeff. & t-stat. & Coeff. & t-stat. & Coeff. & t-stat. \\
\hline$C$ & 1.5769 & $2.8207 * * *$ & 1.1361 & $2.2561 * *$ & 4.7826 & $1.6708^{*}$ \\
\hline CFOt & 0.8115 & $3.1521 * * *$ & 0.8973 & $2.7918^{* * *}$ & 1.4858 & $1.4491^{*}$ \\
\hline TACCt & 0.7238 & $2.7920 * * *$ & 1.0346 & $2.1775^{* *}$ & 0.5853 & 0.8916 \\
\hline LN_TAt-1 & -0.0528 & $-2.6422 * * *$ & -0.0362 & $-2.0459 * *$ & -0.1800 & $-1.7280 * *$ \\
\hline DYear11 & 0.0517 & 0.6449 & 0.0092 & 0.1108 & 0.2624 & $1.7159^{*}$ \\
\hline DYear12 & 0.1382 & $1.7271^{* *}$ & 0.0802 & 0.9447 & 0.5137 & 1.3081 \\
\hline$R^{2}$ & 0.0254 & & 0.02411 & & 0.0823 & \\
\hline Adj. $R^{2}$ & 0.0184 & & 0.0160 & & 0.0325 & \\
\hline $\begin{array}{l}\text { S.E. of } \\
\text { regression }\end{array}$ & 0.8567 & & 0.7981 & & 1.1500 & \\
\hline$F$-statistic & & 3.6369 & & 0.0118 & & 0.1545 \\
\hline $\operatorname{Prob}(F$-statistic $)$ & & 0.0030 & & $<0.01$ & & 0.1064 \\
\hline DW-Statistic & & 2.0536 & & 1.8763 & & 1.9499 \\
\hline \multicolumn{7}{|c|}{ Panel B: The impact of total accruals to abnormal return based on the firms' size } \\
\hline & \multicolumn{3}{|c|}{ Smaller $(n=352)$} & \multicolumn{3}{|c|}{ Larger $(n=353)$} \\
\hline Variable & & Coeff. & $t$-stat. & $\mathrm{Coc}$ & & $t$-stat. \\
\hline$C$ & & 0.6887 & 0.4713 & 0.12 & & 0.1869 \\
\hline CFOt & & 0.4863 & 0.8110 & 0.30 & & 0.5309 \\
\hline TACCt & & 0.4895 & 0.8703 & 1.49 & & $1.6552 * *$ \\
\hline DYear11 & & -0.0182 & -0.3186 & -0.0 & & -0.0183 \\
\hline DYear12 & & 0.0140 & 0.1096 & -0.0 & & -0.7488 \\
\hline
\end{tabular}


Table 3 The impact of total accruals to abnormal return (continued)

\begin{tabular}{lcccc}
\hline \multicolumn{4}{l}{ Panel B: The impact of total accruals to abnormal return based on the firms' size } \\
\hline \multicolumn{4}{c}{ Smaller $(n=352)$} & \multicolumn{2}{c}{ Larger $(n=353)$} \\
\hline Variable & Coeff. & $t$-stat. & Coeff. & $t$-stat. \\
\hline$R^{2}$ & 0.0078 & & 0.0433 & \\
Adj. $R^{2}$ & -0.0066 & 0.0295 & \\
S.E. of regression & 1.0671 & & 0.7665 & 3.1386 \\
$F$-statistic & & 0.5386 & & 0.0087 \\
Prob(F-statistic $)$ & & 0.7470 & & 2.1413 \\
DW-Statistic & & 2.0907 & & \\
\hline
\end{tabular}

***, ** and * indicate significance at the 1,5 and $10 \%$ levels, respectively. Constanta (C), DYear11 and Dyear12 are two tailed. $\mathrm{CFO}_{\mathrm{t}}, \mathrm{TACC}_{\mathrm{t}}$ and $\mathrm{Ln}_{-} \mathrm{TA}_{\mathrm{t}-1}$ are one tailed. $\mathrm{CFO}_{t}$ is operating cash flow in year t. TACC $\mathrm{t}_{\mathrm{t}}$ is total accruals in year $t . \mathrm{LN}_{-} T \mathrm{~A}_{\mathrm{t}-1}$ is natural logarithm of total assets at the beginning of year $\mathrm{t}$. $\mathrm{CFO}_{\mathrm{t}}, \mathrm{TACC}_{\mathrm{t}}$ are scaled by total assets at the beginning of year t. DYear11 (DYear12) is 1 when $t=2011(t=2012)$, and 0 otherwise.

This study also evaluate the impact of total accruals to abnormal return by dividing sample based on the profit and loss firms, that is shown in Table 3 Panel A, in which all samples are divided based on the positive net income sample and negative net income sample. In profit firms, accounting accruals positively affect abnormal return. Using this sample, $\mathrm{H}_{2}$ is supported. In this condition, abnormal return is also affected by operating cash flow, but accruals produce bigger coefficient than operating cash flow. In loss firms, this study presents that total accruals are not able to explain abnormal return, but operating cash flow is. Using this sample, $\mathrm{H}_{2}$ is not supported.

To complement the results, we also present the impact of total accruals to abnormal return based on the firms' size. Those are provided in Table 3 Panel B, which describes the results of smaller firms' sample and larger firms' sample. Using data of smaller firms, Table 3 Panel B shows that total accruals are insignificant to abnormal return. That finding indicates that total accruals have no ability to produce abnormal return for small companies. For larger companies, Table 3 Panel B presents that only total accruals affect abnormal return significantly.

\subsection{Discussion}

This research examines the role of accruals information to risk and return. This research will give benefit not only for market-based accounting research but also investment and trading strategy literatures in developing market.

Our tests support the first hypothesis. The results provide evidence that the higher accruals generate lower stock risk. Implicitly, our study is consistent with Michelson, Wagner and Wootton (1995) that provide argument managing earnings trough accruals stimulates lower stock risk.

After dividing sample based on the performance, our study finds asymmetry behaviour in processing accruals information. Investors' reaction for good news (positive earnings) is different with bad news (negative earnings; Conrad, Cornell and Landsman, 2002; Skinner and Sloan, 2002). In good news, accruals do not affect significantly to stock risk because their expectations are already confirmed. But, dealing with bad news 
(negative earnings) investors will investigate further to earnings components (accruals and operating cash flow). Small (large) firms tend to produce higher (lower) volatility. It means for small firms, the impact of accruals as an earnings component is more observable, because information about those firms is limited. Analysts focus on large firms; therefore they become more informative than small firms. So, with the same information content, information from small firms will bring bigger reaction from the market than those from large firms. This explanation answers that asymmetry impact of accruals to risk.

Our statistical tests also support the second hypothesis. We provide evidence that higher accruals produce higher return. Earnings-return studies provide supporting evidence. When earnings information is divided by accruals and operating cash flow, both of those items should positively affect abnormal return. This result is consistent with many previous studies (Kim and Kross, 2005). In the second test, there is also asymmetry reaction between loss and profit firm. This is consistent with prospect theory that discusses about asymmetry behaviour in loss and gain condition. Conrad, Cornell and Landsman (2002) explain this phenomenon from market perspective and Burgstaghler and Dichev (1997) discuss from managerial perspective. For additional analysis, we categorise our sample based on the profitability and size. In this study, we present the results using split sample because both of the categories have already reflected in our regression variables. For profitability has already covered in variables $\mathrm{TACC}_{\mathrm{t}}$ and $\mathrm{CFO}_{\mathrm{t}}$, and for size has already reflected in $\mathrm{Ln}_{-} \mathrm{TA}_{\mathrm{t}-1}$. We also run our regression using dummy variable for both categories and the tests produce the same results.

Overall, we find that in loss and small firm, accruals' information is useful to anticipate stock risk. Conversely, in profit and bigger firms, accruals' information can be used to explain abnormal return.

\section{Conclusion}

Our findings conclude two important things. First, total accruals' information negatively affects stock risk, especially for loss and small firms. Second, the higher (lower) accruals generate higher (lower) stock return, especially for profit and large firms. Using deeper analysis, we find that operating cash flow information negatively (positively) affects stock risk (abnormal return), but the impact to abnormal returns is bigger. Large (small) firms stimulate lower (higher) stock risk for profit firms. Conversely, large (small) firms produce lower (higher) return.

These results contribute to investors and investment managers. They can use accruals information as trading strategy to minimise their risk and maximise their return. Profit (or loss) condition and companies' size may also interact with accruals to explain stock risk and return. Our research also contributes to market-based accounting research, especially in discussing stock risk. There are many studies focus on return, and in addition, this study evaluates the impact of accrual to risk and return.

Several caveats apply to this study. First, we need to expand more data to find the impact of different economic condition. Although our study already controls year's effect, the longer duration may explain different results. Second, this study can be developed by using more detail items of earnings components and earnings management model. The third, future researches may use international data to discuss about the impact of accruals to risk and return. 


\section{References}

Ambarriani, A.S. (2014) 'Hospital financial performance in the Indonesian national health era', Review of Integrative Business and Economics Research, Vol. 4, No. 1, pp.367-379.

Bartov, E., Givoly, D. and Hayn, C. (2002) 'The rewards to meeting or beating earnings expectations', Journal of Accounting and Economics, Vol. 33, pp.173-204.

Bernard, V.L. and Stober, T.L. (1989) 'The nature of information in cash flows and accruals', Accounting Review, Vol. 64, pp.624-652.

Burgstaghler, D. and Dichev, I. (1997) 'Earnings management to avoid earnings decreases and losses', Journal of Accounting and Economics, Vol. 24, pp.99-126.

Collins, D.W. and Hribar, P. (2000). 'Earnings-based and accruals-based market anomalies: One effect or two?' Journal of Accounting and Economics, Vol. 29, pp.101-123.

Conrad, J., Cornell, B. and Landsman, W.R. (2002) 'When is bad news really bad news?', Journal of Finance, Vol. 57, pp.2507-2532.

Dechow, P.M. 1994. 'Accounting earnings and cash flows as measures of firm performance: The role of accounting accruals', Journal of Accounting and Economics, Vol. 18, pp.3-42.

DeFond, M., Hung, M. and Trezevant, R. (2007) 'Investor protection and the information content of annual earnings announcements: international evidence', Journal of Accounting \& Economics, Vol. 43, pp.37-67.

Fan, J.P.H. and Wong, T.J. (2002) 'Corporate ownership structures and the informativeness of accounting earnings in East Asia', Journal of Accounting and Economics, Vol. 33, No. 3, pp.401-425.

Gordon, M.J. (1964) 'Postulates, principles and research in accounting', The Accounting Review, Vol. 39, No. 2, pp.251-263.

Gunaasih, S.A.P. and Nursasmito, I. (2015). 'The evaluation of non-economic events towards the LQ-45 index in Indonesia stock exchange by using event study method', Review of Integrative Business and Economics Research, Vol. 4, No. 2, pp.106-120.

Healy, P.M. (1985) 'The effect of bonus schemes on accounting decisions', Journal of Accounting and economics, Vol. 7, pp.85-107.

Hepworth, S.R. (1953). 'Smoothing periodic income', The Accounting Review, Vol. 28, No. 1, pp.32-39.

Hirshleifer, D., Hou, K. and Teoh, S.H. (2012) 'The accruals anomaly: risk or mispricing?', Management Science, Vol. 58, No. 2, pp.320-335.

Jones, J. (1991). 'Earnings management during import relief investigation', Journal of Accounting Research, Vol. 29, pp.193-228.

Kim, O. and Kross, W. (2005) 'The ability of earnings to predict future operating cash flows has been increasing-not decreasing', Journal of Accounting Research, Vol. 43, pp.753-780.

Leuz, C., Nanda, D. and Wysocki, P.D. (2003) 'Earnings management and investor protection: an international comparison', Journal of Financial Economics, Vol. 69, pp.505-527.

Liberty, S.E. and Zimmerman, J.L. (1986) 'Labor union contract negotiations and accounting choice', The Accounting Review, Vol. 61, pp.692-712.

Lev, B. and Kunitzky, S. (1974). 'On the association between smoothing measures and the risk of common stocks', Accounting Review, Vol. 49, No. 2, pp.159-270.

Michelson, S.E., Wagner, J.J. and Wootton, C.W. (1995) 'A market based analysis of income smoothing', Journal of Business Finance and Accounting, Vol. 22, No. 8, pp.1179-1193.

Skinner, D.J. and Sloan, R.G. (2002) 'Earnings surprises, growth expectations, and stock returns or don't let an earnings torpedo sink your portfolio', Review of Accounting Studies, Vol. 7, pp.289-312.

Sloan, R.G. (1996) 'Do stock prices fully reflect information in accruals and cash flow about future earnings?', The Accounting Review, Vol. 71, No. 3, pp.289-315. 
International Journal of

Globalisation

and Small Business 


\section{International}

\section{Journal of}

\section{Globalisation and Small}

\section{Business}

Volume 9, No. 1, 2017

Publisher's website: www.inderscience.com

Email: editorial@inderscience.com

ISSN (Print): 1479-3059

ISSN (Online): 1479-3067

Copyright $\odot 2017$ Inderscience Enterprises Ltd

No part of this publication may be reproduced stored or transmitted in any material form or by any means (including electronic, mechanical, photocopying, recording or otherwise) without the prior written permission of the publisher, except in accordance with the provisions of the Copyright Designs and Patents Act 1988 or under the terms of a licence issued by the Copyright Licensing Agency Ltd or the Copyright Clearance Center Inc.

Published and typeset in the UK by Inderscience Enterprises Ltd 


\section{Contents}

\section{SPECIAL ISSUE: REFORMS IN FINANCIAL MANAGEMENT OF SMALL- TO-MEDIUM ENTERPRISES AND GLOBAL FINANCIAL INTEGRATION}

Guest Editor: Michael K. Fung

$1 \quad$ Editorial

Michael K. Fung

3 Factors determining stock returns in property, real estate and construction companies in Indonesia

Henny Medyawati and Muhamad Yunanto

20 Do accrual minimise (maximise) stock risk (return)?: evidence from Indonesia

Dedhy Sulistiawan and Felizia Arni Rudiawarni

29 Relationships among intellectual capital, financial performance and market value: a case study from Indonesia Noorina Hartati and Rini Dwiyani Hadiwidjaja

46 Clustering Indonesian companies' Annual Reports: preliminary assessment of the implementation of integrated reporting by Indonesian listed companies Arie Pratama

55 The contribution of Islamic bank towards the stability of financial system in Indonesia

Munawar Ismail, Ghozali Maskie and Dita Nurul Aini

61 Green Bond and shareholders' wealth: a multi-country event study Siti Nurhidayah Mohd Roslen, Lee Sin Yee and Salizatul Aizah Binti Ibrahim

70 Asymmetric causality between exchange rate and interest rate differentials: a test of international capital mobility

Jauhari Dahalan and Umar Mohammed 